\title{
The Relationship Learning Education of Religion Islamic on Honest Behavior In Class 8 Junior High School of Ibnu Aqil Bogor
}

\author{
Muhamad Syamsul Ma'arif ${ }^{1 a^{*}}$, M. Dahlan $\mathbf{R}^{1, b}$ and Suyud Arif ${ }^{1, c}$ \\ ${ }^{1}$ Faculty of Islamic Education Bogor Ibn Khaldun University Indonesia \\ a muhamadsyamsulmaarifsamsul76@gmail.com; b dahlan@uika-bogor.ac.id; c suyud@uika-bogor.ac.id \\ *Coresponding outhor \\ Whatsapp number: [+62-877705 90709]
}

How to Cite: Ma'arif, M., S. Dahlan R., M. Arif, S. (2019). The Relationship Learning Education of Religion Islamic on Honest Behavior In Class 8 Junior High School of Ibnu Aqil Bogor. International Journal for Educational and Vocational Studies, 1(3), 261-267

\section{ARTICLE HISTORY}

Received: 8 May 2019

Revised: 16 June2019

Accepted: 14 July 2019

\section{KEYWORDS}

Honest,

Islamic religious education,

Learning

\begin{abstract}
Islamic religious education is an effort made to develop all human potential both physically and mentally so that the formation of a whole Muslim person. Islamic education places humans as creatures created by Allah SWT. Thus, Islamic religious education is important in shaping the character of students, one of which is an honest character. The aim to be achieved is to find out the relationship between learning Islamic religious education towards students' honest behavior. The research method used is quantitative research by random sampling as a research sample selection technique. School chosen as research is a school that has implemented the 2013 Class 8 curricula in Ibnu Aqil Middle School, Bogor Regency. based on this, 54 students were selected as the study sample consisting of classes A to $F$, which each class took 9 people as the study sample. Data collection was done using a questionnaire based on a Likert scale assessment. Before being used to collect the data needed in research, the validity of the instrument was tested using SPSS. The results of the study explains that there is a significance of 0,000 less than 0.05 which means $(\mathrm{Ho})$ is rejected, and there is a correlation value of 0.679 which means $(\mathrm{Ha})$ is accepted, which means there is a significant positive relationship between learning Islamic education (variable X) on behavior honest students (variable Y), it can be concluded that learning Islamic education has a significant relationship to honest behavior in Ibn Aqil Middle School, Bogor Regency.
\end{abstract}

This is an open access article under the CC-BY-SA license.

\section{INTRODUCTION}

Islamic religious education is an effort made to develop all human potential both physically and mentally, so that the formation of a whole Muslim person. (Daulany, 2014) Islamic education places humans as creatures created by Allah SWT. Thus, humans as objects and subjects of education must walk according to the nature of the purpose of life itself, where life is bound by the values contained in the nature of His creator. So, in living life, their attitudes and behavior are in line with that essence, humans will get a happy and meaningful life. Conversely, if it is not in line or contrary to this principle, humans will face various complex problems, which if not resolved will bring destruction. The development of children's behavior is influenced by the environment of residence, the environment that can affect the child's personality such as the family environment, the community environment where the child is located, the child's environment receives formal education and teaching. (R. Dahlan, 2016) In these three environments children's behavior will be formed - through association and education. If the education provided by the three environments is good then the child will automatically become a good and beneficial human being for himself, the surrounding community, nation and state. if the education provided by the environment is bad then it will be a person who has bad personality and is useless, for that Islamic religious education needs to be instilled in children both in the family environment, community, and school environment in order to foster mental spirituality so the child Islamic personality education is education that teaches attitudes and behaviors so that the formation of a complete personality, Islamic education is more shown to mental improvement that will be realized in deeds according to the instructions of Islamic teachings, because Islamic education is not only theoretical but it is also practical or Islamic education is at the same time a faith education and charity education (Darajat, 2014). It can be concluded that Islamic religious education is education that is able to form a complete Muslim personality, so that a good, moral and ethical 
personality is formed which is not only intelligent in intellectual but also intelligent in spirituality, this intelligence will deliver people to the real purpose of life namely worship and fear of Allah SWT so that it can be useful both in the world and in the hereafter.

Islamic religious education is very important to be studied as a process that leads to the formation of noble character or personality based on religious values and norms, to achieve a Muslim's life which is to grow human consciousness as a creature of Allah SWT. (R. Dahlan, 2018)

By studying Islamic religious education it is expected to produce changes that are permanent so that in the final stage there will be changes in knowledge, attitudes, values, and skills. Changes obtained from the learning process and learning of Islamic religious education can be practiced in everyday life behaviors. One of the successful goals of Islamic education is the formation of good attitudes or characters so that they can be applied in daily life, both at school and in the community. So many characters or attitudes that support one's success, the character that must be possessed by students is one of them is an honest character.

Honesty is a value of someone's decision to express (in the form of feelings, words and/or actions) that the reality is not manipulated by means of lying or deceiving others to their advantage. The word honest is identical to "true" which the opponent says is "lying". Honest meaning is further correlated with goodness (benefit). Benefit has the meaning of the interests of many people, not the interests of themselves or their groups, but all those involved. (Dharma, 2011).

Based on interviews with Islamic education teachers, he said that the school had developed an honest character in the development of the school curriculum. For example, the teacher asks people how to pray at home after the child is given a book of worship activities to be filled by the child at home. Even so, but there are still students who have lost items, such as pencils, pens, erasers, and cellphones. This seems to be a normal activity carried out by students at school.

Based on the above thoughts, the authors are interested in further examining the extent to which students 'understanding of learning Islam relates to students' honest behavior, therefore the researcher takes the theme "The Relationship of Learning to Islamic Education Against Honest Behavior in Grade 8 Students of Ibnu Aqil Junior High School in Bogor. The aim of this research is to find out the relationship between learning Islamic religious education towards students' honest behavior

\section{MATERIALS AND METHODS}

\subsection{Islamic Education Learning}

\subsubsection{Definition of Learning}

According to Oemar Hamalik (Ramayulis, 2015: 339) Learning is a combination that consists of human, material, facilities, equipment and procedures that influence each other to achieve learning goals, in this case humans are involved in the teaching system consisting of students, teachers and other energy, the material consists of books, blackboards and others.

\subsubsection{Definition of Islamic Education}

According to Tayar Yusuf (1986: 35) in (Abdul Majid, 2005: 130) defining Islamic religious education is a conscious effort of the older generation to divert experience, knowledge, skills and skills to the younger generation so that later they will become fearful humans to Allah SWT. According to (Daulany, 2014: 11) "Islamic Education is an effort made to develop all human potential both physically and mentally so that the formation of a whole Muslim person." According to A. Tafsir dalam (Abdul Majid, 2005: 130) Islamic religious education is guidance given by someone to someone to develop optimally in accordance with Islamic teachings.

\subsubsection{Platform for Islamic Education}

"It is said that there are four sources of Islam, the first is Al-Qur'an, second is Sunnah or Hadith, third is Ijma 'and fourth Qiyas. The so-called al-adillat al-gath 'iyyah, namely the arguments or theorems that are truly absolute, and al-adillat al-ijtihadiyah, namely the arguments or theorems obtained by using and directing the ability of the mind. Ijma 'and Qiyas cannot be called Islamic sources, because both are just ways or paths, means to arrive at a formulation. If people will take water from the well, they can use a bucket and can also use a pump. But buckets and pumps are not a source of water, wells are really the source of water. Ijma 'and Qiyas are just a kind of bucket and pump while the Qur'an is the source ". (Akmal Hawi, 2014: 63-64)

\subsubsection{Objectives of Islamic Education}

According to Marimba (1964: 39) in (Ahmad Tafsir, 2010: 46) the purpose of Islamic education is the formation of people who are Muslim personalities. Islam wants people to be educated so they can realize their life goals. Whereas according to (Zakia Darajat, 2014: 29) the ultimate goal of Islamic education is the formation of human beings who are human beings with the pattern of piety, insan kamil means intact spiritual and physical, can live and develop naturally and normally because of his devotion to Allah SWT.

\subsubsection{Scope of Islamic Education}

The scope of Islamic religious education includes the entire teachings of Islam carried by the Prophet Muhammad. Teachings that contain basic guidelines governing various aspects of life for the welfare of human life in the world and end later 


\subsection{Honest}

\subsubsection{Honest Understanding}

According to the Kamus Besar Bahasa Indonesia (KBBI.web.id). Honest means being upright, not cheating, and being respected. People who say or act or do the truth, according to their conscience and do not underhanded. In religious terms, "honest" is synonymous with the word ash-shidq, meaning "true". Saying or doing right means also saying or acting honestly. According to Riyadhus Shalihin in (Ahmad Tafsir, 2017: 66) stated that truth and honesty are goodness and a way of salvation, and an act will be judged only because of its sincerity and honesty. In a hadith, the Prophet said: "Verily honesty leads to goodness, and goodness leads to heaven. Hopefully, someone always be honest so that he is written by Allah as an honest person. Surely that lie leads to evil, and evil brings to hell. hopefully, someone always lies until it is written by Allah as a liar. "(Muttafaq alaih) (Ahmad Tafsir, 2017: 66).

\subsubsection{Types of Honest}

\section{Honest in speaking}

Honest in words is a form of fame. Every servant is obliged to take care of his utter, that is speaking honestly and is encouraged to avoid satirical words because it is worth the lie, except if it is needed and for the benefit of certain moments.

\section{Honest in intention and will}

Honesty depends on one's sincerity. If his charity is not pure for Allah SWT, but for the sake of his desires it means he is not honest in his intentions, it can even be said to have lied, as told in the hadith about three people (Hurairah 2014) in (Al-Mishri, 2008: 26) namely people who often read the Qur'an, people who often give alms, and mujahid.

\section{Honest in desiring and implementing it}

The intention or determination that is intended is like someone's saying, "If God gives me wealth, I will devote everything." This determination is said sometimes with sincerity and sometimes with doubt.

Table 1. Student Data

\begin{tabular}{ccccc}
\hline No. & Class & Famale & Male & Amount \\
\hline 1. & VIII A & 19 & 14 & 33 Student \\
2. & VIII B & 24 & 13 & 37 Student \\
3. & VIII C & 20 & 17 & 37 Student \\
4. & VIII D & 21 & 16 & 37 Student \\
5. & VIII E & 20 & 16 & 36 Student \\
6. & VIII F & 19 & 16 & 35 Student \\
& \multicolumn{2}{c}{ Amount } & & 215 Student \\
\hline
\end{tabular}

\section{Honest in acting}

Honesty in acting means there is no difference between intention and action. Being honest in this case can also mean not pretending to be charitable in charity while his heart isn't.

\section{Honest in terms of religion}

Being honest in religion is the highest degree of honesty, such as being honest in fear of Allah SWT, hoping for His pleasure, zuhud, willing with His giver, love and trust.

\section{Characteristics of Honest Attitude}

According to (Beginning in 2017) honest character has the following behavioral characteristics:

1. If the determination (initiation of a decision) to do something, his determination is truth and benefit.

2. If you say don't lie, say or give information in accordance with reality.

3. If there is a similarity between what the heart says and what it does.

\subsection{Types of Research}

This type of research is quantitative research. According to (Juliansyah Noor, 2015: 38) suggests quantitative research is a method for testing certain theories by examining the relationships between variables. These variables are measured (usually by research instruments) so that data consisting of numbers can be analyzed based on statistical procedures.

\subsection{Place and Time}

The place and time of this research was conducted at IBNU AQIL BOGOR Junior High School (AKREDITASI A). Jl.Laladon No. 256 Ex. Laladon Kec. Ciomas Kab. Bogor 16610. While the time of the research that the author planned to begin on February 6 - March 2019.

\subsection{Population and Samples}

\subsubsection{Population}

Population is the whole subject of research. If someone wants to examine all the elements in the research area, the research is population research. His studies or research are also called population studies or census studies. In the Encyclopedia of Educational Evaluation it is written: "Population is a set (or collection) of all elements of processing one or more interesting attributes." (Suharsimi Arikunto, 2013: 173). The population in this study were all Grade VIII students of IBNU AQIL Middle School, Bogor Regency, which amounted to 215 people. 


\subsubsection{Samples}

The sample is part of the number and characteristics possessed by the population. If the population is large, and researchers are not likely to learn all that exists in the population, for example due to limited funds, energy and time, the researcher can use samples taken from that population. What is learned from the sample, the conclusions can be applied to the population. For that samples taken from the population must be truly representative (represent) (Suharsimi Arikunto, 2010: 174).

Table 2. Population and Sample

\begin{tabular}{cccc}
\hline No & Class & Populasi & Sample \\
\hline 1 & VIII A & 33 & 9 \\
2 & VIII B & 37 & 9 \\
3 & VIII C & 37 & 9 \\
4 & VIII D & 37 & 9 \\
5 & VIII E & 36 & 9 \\
6 & VIII F & 35 & 9 \\
& Amount & 215 & 54 \\
\hline
\end{tabular}

\subsection{Data Collection Techniques}

The data collection technique is part of the data collection instrument that determines the success or failure of a study (Burhan Bungin, 2013: 133). Data collection techniques needed by this type of quantitative research are: (observation, interview, documentation study, and questionnaire or questionnaire).

\subsection{Research Instruments}

The research instrument was used to measure the value of the variables to be examined. The number of instruments used depends on the number of variables studied. If there are three research variables, then the number of instruments to be used is also three. There are research instruments made by researchers and there are also those that have been standardized by experts, because this research instrument will be used to make measurements aimed at producing precise and accurate quantitative data, then each instrument must have a clear scale (Riduwan, 2015: 78). The assessment scale uses a Likert scale, the Likert scale is a technique of measuring attitudes where subjects are asked to identify their level of agreement or disagreement with each statement. In the Likert scale is manifested in four positive options, strongly agree (SS) score 4, Agree (3), disagree (2) and disagree (1). While the negative statement forms are given a score, namely; strongly agree (SS) score 1, Agree (2), disagree (3) and disagree (4).

Table 4. Variable Grid Y Honest Behavior of Students

\begin{tabular}{cccc}
\hline No. & Indicator & $\begin{array}{c}\text { No. } \\
\text { Questions }\end{array}$ & No. Questionnaire \\
\hline 1. & Faith & 5 & $1,2,3,4,5$ \\
2. & Al-Qur'an Hadist & 5 & $6,7,8,9,10$ \\
3. & Morals & 5 & $11,12,13,14,15$ \\
4. & Fiqh / Worship & 5 & $16,17,18,19,20$ \\
5. & Date / History & 5 & $21,22,23,24,25$ \\
\hline
\end{tabular}

\subsection{Data Analysis Methods}

\subsubsection{Test of Analysis Terms}

\section{Validity}

According Arikunto (1995: 63) in (Riduwan, 2015: 97) explains that what is meant by validity is a measure that shows the level of reliability or validity of a measuring instrument. Likewise according to Sugiono in (Riduwan, 2015: 97) the instrument is said to be valid means showing the measuring instrument used to obtain the data is valid so that the instrument can be used to measure what should be measured. After the data is obtained and tabulated, the assessment of the validity of construction is done by factor analysis, which correlates between the scores of instrument items with SPSS calculations. See Table 3. Variable Grid X Islamic Learn

\begin{tabular}{clcl}
\hline No & \multicolumn{1}{c}{ Indicator } & No. Question & No. questionnair \\
\hline 1. & $\begin{array}{l}\text { Convey something with actual } \\
\text { conditions }\end{array}$ & 5 & $1,2,3,4,5$ \\
2. & $\begin{array}{l}\text { Willing to admit to his mistakes, } \\
\text { shortcomings or limitations }\end{array}$ & 5 & $6,7,8,9,10$ \\
3. & 5 & $11,12,13,14,15$ \\
4. & Do not cheat & 5 & $16,17,18,19,20$ \\
5. & Not manipulating facts / & 5 & $21,22,23,24,25$ \\
\hline
\end{tabular}

The decision to test the validity of the instrument is:

1. Item statement is said to be valid if $r$ count $>r$ table

2. The statement is said to be invalid if $r$ count $<r$ table item.

The validity test of the questionnaire was carried out on 54 respondents, for the results of the validity test of the variables $\mathrm{X}$ and $\mathrm{Y}$, namely: Learning Islamic Education with Student Honest Behavior from each of the 25 statements. Item statements that are declared valid and invalid can be seen in the table below:

Table 5. Test Results for Validity of Variables $X$

\begin{tabular}{|c|c|c|c|}
\hline No & $r_{\text {count }}$ & $r_{\text {table }}$ & Description \\
\hline 1. & 0,365 & 0,266 & Valid \\
\hline 2. & 0,528 & 0,266 & Valid \\
\hline 3. & 0,297 & 0,266 & Valid \\
\hline 4. & 0,289 & 0,266 & Valid \\
\hline 5. & 0,384 & 0,266 & Valid \\
\hline 6. & 0,437 & 0,266 & Valid \\
\hline 7. & 0,311 & 0,266 & Valid \\
\hline 8. & 0,513 & 0,266 & Valid \\
\hline 9. & 0,314 & 0,266 & Valid \\
\hline 10. & 0,517 & 0,266 & Valid \\
\hline 11. & 0,654 & 0,266 & Valid \\
\hline 12. & 0,513 & 0,266 & Valid \\
\hline 13. & 0,342 & 0,266 & Valid \\
\hline 14. & 0,668 & 0,266 & Valid \\
\hline 15. & 0,273 & 0,266 & Valid \\
\hline 16. & 0,504 & 0,266 & Valid \\
\hline 17. & 0,491 & 0,266 & Valid \\
\hline 18. & 0,484 & 0,266 & Valid \\
\hline
\end{tabular}




\begin{tabular}{llll}
\hline 19. & 0,345 & 0,266 & Valid \\
20. & 0,504 & 0,266 & Valid \\
21. & 0,588 & 0,266 & Valid \\
22. & 0,670 & 0,266 & Valid \\
23. & 0,589 & 0,266 & Valid \\
24. & 0,422 & 0,266 & Valid \\
25. & 0,481 & 0,266 & Valid \\
\hline
\end{tabular}

Based on the table above it can be concluded that the number of items of honest student behavior is obtained as a whole. The item is 25 items.

\section{Reliability}

According to (Suharsimi Arikunto, 2010: 221) Reliability is referring to an understanding that something an instrument is sufficiently reliable to be used as a data collection tool because the instrument is good. A good instrument will not be tendentious in that it directs respondents to choose certain answers. Instruments that can be trusted, which are reliable will produce reliable data too. If the data is indeed in accordance with reality, then several times it is taken, it will still be the same. Reliability refers to the level of reliability of something. Reliability means, can be trusted, so it can be relied upon.

Because the correlation index obtained just shows the relationship between the two halves of the instrument, then to obtain the reliability index the question must use the SPSS calculation

Table 6. Reliability Statistics

\begin{tabular}{cc}
\hline Cronbach's Alpha & N of Items \\
\hline, 914 & 25 \\
\hline
\end{tabular}

Based on the above output, it is found that the Cronbach's Alpha coefficient is at the reliability level of 0.914 . The value of 0.914 turns out $>$ from 0.05 so it can be concluded that the questionnaire in this study is reliable.

\section{Normality}

The normality test is done to find out whether the data taken comes from populations that are normally distributed or not. There are several techniques that can be used to test the normality of data, including: with normal chance paper, chi-square test, Liliefors test, and Kolmogorov-Smirnov technique, and SPSS 14 for Windows (Juliansyah Noor, 2011: 174).

Table 7. One-Sampel Kolmogorov-Smirnov Test

\begin{tabular}{llll}
\hline & & SCORE & SCORE \\
& & TOTAL & TOTAL \\
\hline $\mathrm{N}$ & Mean & 84 & 54 \\
\multirow{2}{*}{ Normal Parameters $\mathrm{a}, \mathrm{b}$} & Std. Deviation & 6,161 & 81,59 \\
& Absolute &, 093 & $, 8,873$ \\
\multirow{2}{*}{ Most Extreme Differences } & Positive &, 058 &, 062 \\
& Negative &,- 093 &,- 100
\end{tabular}

$\begin{array}{lll}\text { Test Statistic } & , 093 & , 100 \\ \text { Asymp. Sig. (2-tailed) } & , 200 \mathrm{cod} & , 200 \mathrm{cod}\end{array}$

the table above shows the statistical value is variable $\mathrm{X}$ 0.093 and variable Y 0.100 with a significant value of $0.200>0.05$ so it can be concluded that the data used is normally distributed.

\subsection{Data Analysis}

\subsubsection{Definition of analysis of the Product Moment}

The analysis of Product Moment Correlation's correlation or precisely product of the Moment Correlation is one technique to find correlations between two variables that are often used. This correlation technique was developed by Karl Pearson, which is therefore often known as the Pearson Correlation Technique term. It is called as Product Moment Correlation because the correlation coefficient is obtained by finding the product of the moments of the correlated variable (Product of the Moment) (Anas Sudijono, 2015: 190).

\subsection{Data Interpretation}

According to Anas Sudijono, 2015: 193) argues that in giving a simple interpretation of the figures of the Correlation Index " $r$ " product moment (rxy), the guidelines are generally used as follows.

\begin{tabular}{cc}
\hline $\begin{array}{c}\text { Standard of "r" } \\
\text { Product Moment }\end{array}$ & $\begin{array}{c}\text { Interpretation } \\
\text { Between variables } \mathrm{X} \text { and Variables } \mathrm{Y} \\
\text { there is a correlation, but the correlation } \\
\text { is very weak or very low so the } \\
\text { correlation is ignored (considered there } \\
\text { is no correlation between variables } \mathrm{X} \\
\text { and Variable } \mathrm{Y} \text { ). }\end{array}$ \\
$\begin{array}{c}\text { Between variables } \mathrm{X} \text { and } \mathrm{Y} \text { there is a } \\
\text { weak or low correlation. } \\
0,20-0,40\end{array}$ & $\begin{array}{c}\text { Between variables } \mathrm{X} \text { and } \mathrm{Y} \text { there is a } \\
\text { moderate or sufficient correlation. } \\
\text { Between variables } \mathrm{X} \text { and } \mathrm{Y} \text { there is a } \\
\text { correlation that is very strong or very } \\
\text { high. }\end{array}$ \\
$0,40-0,70$ &
\end{tabular}

\section{RESULTS AND DISCUSSIONS}

\subsection{Description of data $X$}

Table 8. Recapitulation of Questionnaire Score Results Islamic Education Learning

\begin{tabular}{|c|c|c|c|c|c|c|c|c|c|c|}
\hline \multirow{3}{*}{ No. } & \multicolumn{8}{|c|}{ Answer score } & \multirow{2}{*}{\multicolumn{2}{|c|}{ Total }} \\
\hline & \multicolumn{2}{|c|}{4} & \multicolumn{2}{|c|}{3} & \multicolumn{2}{|c|}{2} & \multicolumn{2}{|c|}{1} & & \\
\hline & $\mathrm{F}$ & $\%$ & $\mathrm{~F}$ & $\%$ & $\mathrm{~F}$ & $\%$ & $\mathrm{~F}$ & $\%$ & $\mathrm{~F}$ & $\%$ \\
\hline 1 & 36 & 67 & 17 & 31 & 1 & 2 & - & - & 54 & 100 \\
\hline 2 & 36 & 67 & 18 & 33 & - & - & - & - & 54 & 100 \\
\hline 3 & 27 & 50 & 27 & 50 & - & - & - & - & 54 & 100 \\
\hline 4 & 52 & 96 & 2 & 4 & - & - & - & - & 54 & 100 \\
\hline 5 & 31 & 57 & 20 & 37 & 3 & 6 & - & - & 54 & 100 \\
\hline 6 & 15 & 28 & 37 & 68 & 2 & 4 & - & - & 54 & 100 \\
\hline 7 & 33 & 61 & 21 & 39 & - & - & - & - & 54 & 100 \\
\hline 8 & 19 & 35 & 33 & 61 & 2 & 4 & - & - & 54 & 100 \\
\hline
\end{tabular}




\begin{tabular}{|c|c|c|c|c|c|c|c|c|c|c|}
\hline 9 & 37 & 69 & 17 & 31 & - & - & - & - & 54 & 100 \\
\hline 10 & 14 & 26 & 35 & 65 & 5 & 9 & - & - & 54 & 100 \\
\hline 11 & 11 & 20 & 40 & 74 & 3 & 6 & - & - & 54 & 100 \\
\hline 12 & 12 & 22 & 35 & 65 & 7 & 12 & - & - & 54 & 100 \\
\hline 13 & 24 & 44 & 30 & 56 & - & - & - & - & 54 & 100 \\
\hline 14 & 28 & 52 & 25 & 46 & 1 & 2 & - & - & 54 & 100 \\
\hline 15 & 28 & 52 & 26 & 48 & - & - & - & - & 54 & 100 \\
\hline 16 & 21 & 39 & 30 & 56 & 3 & 5 & - & - & 54 & 100 \\
\hline 17 & 23 & 43 & 31 & 57 & - & - & - & - & 54 & 100 \\
\hline 18 & 44 & 81 & 10 & 19 & - & - & - & - & 54 & 100 \\
\hline 19 & 24 & 45 & 25 & 46 & 5 & 9 & - & - & 54 & 100 \\
\hline 20 & 9 & 17 & 36 & 66 & 9 & 17 & - & - & 54 & 100 \\
\hline 21 & 21 & 39 & 29 & 54 & 4 & 7 & - & - & 54 & 100 \\
\hline 22 & 17 & 32 & 33 & 61 & 4 & 7 & - & - & 54 & 100 \\
\hline 23 & 20 & 37 & 30 & 56 & 4 & 7 & - & - & 54 & 100 \\
\hline 24 & 11 & 21 & 39 & 72 & 4 & 7 & - & - & 54 & 100 \\
\hline 25 & 13 & 24 & 33 & 61 & 7 & 13 & 1 & 2 & 54 & 100 \\
\hline \multirow{2}{*}{ Total } & 60 & 11 & 67 & 12 & \multirow{2}{*}{64} & 11 & \multirow{2}{*}{1} & \multirow{2}{*}{2} & & \\
\hline & 6 & 24 & 9 & 56 & & 7 & & & & \\
\hline Avera & 24 & 44 & 27 & 50 & 2,5 & 4,6 & 0,0 & 0,0 & & \\
\hline ge & 24 & 96 & 16 & 24 & 6 & 8 & 41 & 8 & & \\
\hline
\end{tabular}

Based on the results above it can be concluded that the recapitulation of Islamic religious education learning in Junior High School Ibnu Aqil Bogor alternative answers with a score of 4 on average $44.96 \%$, alternative answers with a score of 3 average $50.24 \%$, alternative answers with a score of 2 averages $4.68 \%$, alternative answers with a score of 1 average of $0.08 \%$. Thus it can be seen that the highest number of answers is an alternative with a score of 3 with an average of $50.2 \%$.

\subsection{Description of data $Y$}

Table 9. Recapitulation of Questionnaire Score Results Student Honest Behavior

\begin{tabular}{|c|c|c|c|c|c|c|c|c|c|c|}
\hline \multirow{3}{*}{ No. } & \multicolumn{8}{|c|}{ Answer score } & \multicolumn{2}{|c|}{ Total } \\
\hline & \multicolumn{2}{|c|}{4} & \multicolumn{2}{|c|}{3} & \multicolumn{2}{|c|}{2} & \multicolumn{2}{|c|}{1} & \multirow[b]{2}{*}{$\mathrm{F}$} & \multirow[b]{2}{*}{$\%$} \\
\hline & $\mathrm{F}$ & $\%$ & $\mathrm{~F}$ & $\%$ & $\mathrm{~F}$ & $\%$ & $\mathrm{~F}$ & $\%$ & & \\
\hline 1 & 12 & 22 & 39 & 72 & 3 & 6 & - & - & 54 & 100 \\
\hline 2 & 17 & 31 & 37 & 69 & - & - & - & - & 54 & 100 \\
\hline 3 & 17 & 31 & 28 & 52 & 8 & 15 & 1 & 2 & 54 & 100 \\
\hline 4 & 27 & 50 & 25 & 46 & 2 & 4 & - & - & 54 & 100 \\
\hline 5 & 17 & 31 & 27 & 50 & 10 & 19 & - & - & 54 & 100 \\
\hline 6 & 21 & 39 & 31 & 57 & 2 & 4 & - & - & 54 & 100 \\
\hline 7 & 27 & 50 & 27 & 50 & - & - & - & - & 54 & 100 \\
\hline 8 & 16 & 29 & 28 & 52 & 9 & 17 & 1 & 2 & 54 & 100 \\
\hline 9 & 35 & 65 & 19 & 35 & - & - & - & - & 54 & 100 \\
\hline 10 & 31 & 57 & 23 & 43 & - & - & - & - & 54 & 100 \\
\hline 11 & 10 & 18 & 29 & 54 & 14 & 26 & 1 & 2 & 54 & 100 \\
\hline 12 & 23 & 43 & 26 & 48 & 4 & 7 & 1 & 2 & 54 & 100 \\
\hline 13 & 8 & 15 & 34 & 63 & 9 & 17 & 3 & 5 & 54 & 100 \\
\hline 14 & 22 & 41 & 29 & 54 & 3 & 5 & - & - & 54 & 100 \\
\hline 15 & 7 & 13 & 35 & 65 & 11 & 20 & 1 & 2 & 54 & 100 \\
\hline 16 & 29 & 54 & 23 & 42 & 2 & 4 & - & - & 54 & 100 \\
\hline 17 & 18 & 33 & 33 & 61 & 3 & 6 & - & - & 54 & 100 \\
\hline 18 & 26 & 48 & 25 & 46 & 3 & 6 & - & - & 54 & 100 \\
\hline 19 & 22 & 41 & 27 & 50 & 3 & 5 & 2 & 4 & 54 & 100 \\
\hline 20 & 33 & 61 & 18 & 33 & 3 & 6 & - & - & 54 & 100 \\
\hline 21 & 4 & 8 & 38 & 70 & 11 & 20 & 1 & 2 & 54 & 100 \\
\hline 22 & 23 & 43 & 25 & 46 & 4 & 7 & 2 & 4 & 54 & 100 \\
\hline 23 & 18 & 33 & 32 & 59 & 4 & 8 & - & - & 54 & 100 \\
\hline 24 & 26 & 48 & 25 & 47 & 3 & 5 & - & - & 54 & 100 \\
\hline 25 & 13 & 24 & 33 & 61 & 7 & 13 & 1 & 2 & 54 & 100 \\
\hline
\end{tabular}

$\begin{array}{ccccccccc}\text { Total } & 50 & 92 & & 13 & 11 & 22 & 14 & 27 \\ & 2 & 8 & 716 & 25 & 8 & 0 & & \\ \text { Avera } & 20, & 37, & & & 4,7 & & 0,5 & 1,0 \\ \text { ge } & 08 & 12 & 28,64 & 53 & 2 & 8,8 & 6 & 8\end{array}$

Based on the above results it can be concluded that the recapitulation of honest behavior in the Ibn Aqil Middle School Bogor alternative answers with a score of 4 on average $37.12 \%$, alternative answers with a score of 3 on average $53 \%$, alternative answers with a score of 2 average $8.8 \%$, alternative answers with a score of 1 average of $1.08 \%$. Thus it can be seen that the highest number of answers is an alternative with a score of 3 with an average of $53 \%$.

To find out the relationship between learning Islamic religious education towards honest behavior of Ibn Aqil Middle School, Bogor Regency, the researcher used SPSS calculations.

Table 10. Correlations

\begin{tabular}{clll}
\hline & & $\begin{array}{l}\text { SCORE } \\
\text { TOTAL }\end{array}$ & SCORE TOTAL \\
\hline SKOR_TO & Pearson Correlation & 1 &, $679^{* *}$ \\
TAL & Sig. (2-tailed) & &, 000 \\
& $\mathrm{~N}$ & 54 & 54 \\
SKOR.TO & Pearson Correlation &, $679^{* *}$ & 1 \\
TAL & Sig. (2-tailed) &, 000 & \\
$*$ **. Correlation is significant at the 0.01 level (2-tailed). &
\end{tabular}

From the output above, it can be seen the value of the person correlation between the learning variables of the Islamic religion and the honest behavior of the students of 0.679. Stars are two meaning significant at the 0.01 level. Positive correlation value means that there is a positive relationship between learning Islamic religious education with honest student behavior. While the closeness of the relationship is sufficient because it is in the range of 0.40-0.70.

To test the significance of the researcher using a two-sided test with a significance level of $a=5 \%$. The testing criteria are Ho accepted if the significance is $>0.05$ and $\mathrm{Ho}_{\mathrm{o}}$ is rejected if the significance is $<0.05$. The significance value of the output above is 0,000 less than 0.05, therefore Ho is rejected and Ha is accepted, meaning that there is a relationship between learning Islamic religious education and honest behavior of students of Ibn Aqil Middle School in Bogor Regency.

\subsection{Discussion}

From the results of the SPSS data the average value of variable $\mathrm{X}$ (Islamic education learning) is 85.00, the median is 85.50 the range is 26 and the value that often appears is 86 . Likewise, the Y (Student Honest Behavior) variable from the SPSS data results obtained an average value of 81.59 , the median of 83.00 , the range of 41 and the value that often appears is 89 .

Based on the results of the two studies above, it explains that there is a significance of 0,000 less than 0.05 
which means (Ho) is rejected, and there is a correlation value of 0.679 which means $(\mathrm{Ha})$ is accepted, which means there is a significant positive relationship between learning Islamic religious education (variable X) towards students' honest behavior (variable Y), it can be concluded that learning Islamic education has a moderate or significant relationship to honest behavior in Ibn Aqil Middle School, Bogor Regency.

\section{CONCLUSION}

Relationship between Islamic Education Learning and Honest Behavior there is ENOUGH position with a significance of 0,000 which means that Ho is rejected and there is a correlation value of 0.679 which means $\mathrm{Ha}$ is accepted. From the results of research conducted by researchers about learning Islamic education on honest behavior of students in the IBNU AQIL Middle School in Bogor Regency, it can be concluded that there is a significant relationship between learning Islamic education towards honest behavior of students with ENOUGH significant levels. So the better the learning of Islamic religious education the better the honest behavior of students at IBNU AQIL Middle School, Bogor Regency.

With the existence of a significant relationship between the learning of Islamic religious education and honest behavior of students, the authors provide several suggestions to all parties concerned as follows:

For Educators It is hoped that in the teaching and learning process educators will not only teach Islamic education subject matter but also provide attitudes or good behavior by exemplifying or associating with daily life and providing knowledge about the scope of Islamic religious education concerning faith, the Qur'an / Hadith, morality, fiqh and history also need to be given to students to form the morality of al-kharimah.

Educators should be good examples for their students. Thus students will be able to choose an appropriate figure and can reflect good character / attitude and become a trustworthy, honest and responsible leader.

For students the success and achievement of a person is not always measured by the level of intelligence, but how he can behave well in all things, this will lead students to achieve success in the world and in the hereafter. If someone's attitude is good then it will produce something good and vice versa. Get used to always being honest in everything, both at school, at home and in the surrounding environment, because that is what will deliver success.

\section{REFERENCES}

Arikunto, S. (2010). Prosedur Penelitian Suatu Pendekatan Praktik, Jakarta: PT. Rineka Cipta.

Arikunto, S. (2013). Prosedur Penelitian Suatu Pendekatan Praktik, Jakarta: PT. Rineka Cipta.
Orang-Orang Jujur, Jawa Tengah: Pustaka Arofah.

Bungin, B. (2013). Metodologi Penelitian Kuantitatif Komunikasi, Ekonomi, Dan Kebijakan Publik Serta Ilmu-Ilmu Sosial Lainnya, Jakarta: Kencana Prenada Media Group.

Daradjat, Z. (2014). Ilmu Pendidikan Islam, Jakarta: Bumi Aksara

Daulay, H. (2014). Pendidikan Islam dalam Perspektif Filsafat, Jakarta: Kencana Prenadamedia Grup.

Kesuma, D. (2011). prndidikan karakter, Bandung: PT. Remaja Rosdakarya

Hulaini, Nila. 2017. Impelentasi Pendidikan Karakter Jujur Dalam Membentuk Kepribadian Siswa Kelas VII Di SMP Negeri 19 Palembang. Skripsi. Diterbitkan. Palembang: FITK UIN Raden Fatah.

Juliansyah, N. (2015). Metodologi Penelitian Skripsi, Tesis, Desertasi, Dan Karya Ilmiah, Jakarta: Prenada Media Group.

Ramayulis 2015. Ilmu Pendidikan Islam, Jakarta: Kalam Mulia.

R. Dahlan. (2018). Relavansi Pemahaman Agama Dengan Interaksi Sosial Siswa (Studi Pada Sekolah Menengah Atas Negri (SMAN) Se-Kecamatan Tanah Sareal, Kota Bogor, Penamas, 31(02), 297-310.

R. Dahlan. (2016). Konsep Pembelajaran Aqidah Akhlak, Yogyakarta: CV Budi Utama.

Riduwan. (2015). Belajar Mudah Penelitian Untuk Guru-Karyawan dan Peneliti Pemula, Bandung: Alfabeta Cv.

Sudijono, A. (2015). Pengantar Statistik Pendidikan, Jakarta: PT. Raja Grafindo.

Sugiyono. (2009). Metode Penelitian Kuantitatif Kulitatif Dan $R \& D$, Bandung: Alfabeta.

Sukardi. (2013). Metodologi Penelitian Pendidikan, Jakarta: PT. Bumi Aksara. 